\title{
To the Editor,
}

University Hospital North Norway 18. June 2011

We refer to our article published in your journal: Murad MK \& Husum H. Trained lay first-helpers reduce trauma mortality: a controlled clinical study of rural trauma in Iraq [1].

Our colleagues, Wisborg and Gilbert, has brought to our attention an error in Table 2 in the final print of the article. In the print the table reads:

\begin{tabular}{|c|c|c|c|c|c|c|}
\hline & 4 & 3 & 2 & 1 & 0 & score \\
\hline respiratory rate & $10-30$ & $>30$ & $6-9$ & $1-5$ & no breathing & \\
\hline $\begin{array}{l}\text { systolic blood } \\
\text { pressure }\end{array}$ & $>90$ & $76-89$ & $50-75$ & $1-49$ & no carotid pulse & \\
\hline $\begin{array}{l}\text { level of } \\
\text { consciousness }\end{array}$ & awake & confused & $\begin{array}{l}\text { responds to } \\
\text { sound }\end{array}$ & $\begin{array}{c}\text { responds to pain } \\
\text { only }\end{array}$ & no response & \\
\hline & & & & & & PSS SUM \\
\hline
\end{tabular}

Table 2-Physiological Severity Scope

The cut-off values for the respiratory rate and systolic blood pressure in this table are incorrect. The values actually registered and used for the Trauma Registry analysis throughout the 10-year study period are:

\begin{tabular}{|l|c|c|c|c|c|}
\hline & 4 & 3 & 2 & 1 & 0 \\
\hline respiratory rate & $10-24$ & $25-35$ & $>35$ & $<10$ & no breathing \\
\hline systolic blood pressure & $>90$ & $70-90$ & $50-69$ & $<50$ & no carotic pulse \\
\hline
\end{tabular}

These cut-off values have also been used for previous studies of the Iraqi Trauma Registry $[2,3]$. The cut-off values are slightly different from the original values used in the Revised Trauma Score [4]. However, previous studies document that they predict trauma deaths with high accuracy (ROC Area-under-curve > 0.90) $[5,6]$ which is why they were used for the analysis of first-responder effect in the actual article in your journal.

We apologize for the mistake, which is the sole responsibility of the corresponding author. We also acknowledge the watchfulness of the readers of the journal and kindly ask the editor to publish this erratum.

Sincerely, Mudhafar Kareem Murad (sign)

$$
\text { Maus Husiunn }
$$

Hans Husum (sign), author of correspondence 